\title{
PENERAPAN PENDIDIKAN ISLAM ANTI-RADIKALISME DALAM MERAJUT HARMONI: Suatu Tinjauan di Kota Sungai Penuh Jambi
}

\author{
Masnur Alam ${ }^{1}$, Wisnarni $^{2}$, Yoki Irawan ${ }^{3}$ \\ 1,2,3IAIN Kerinci \\ 1,2,3Jl. Pelita IV, Sungai Penuh, Sumur Gedang, Kerinci, Jambi \\ Email: masnur.alam@yahoo.com¹, wis_narni@gmail.com²,ykrwn09@gmail.com³
}

\begin{abstract}
Abstrak:
Tujuan penelitian ini adalah untuk mengetahui penerapan pendidikan Islam anti radikalisme dalam merajut harmoni di Kota Sungai Penuh. Jenis penelitian ini adalah deskriptif dengan pendekatan kualitatif. Pengumpulan data dilakukan dengan metode wawancara, observasi dan telaah dokumen. Hasil penelitian menunjukkan bahwa Kota Sungai Penuh telah menerapkan pendidikan Islam anti-radikalismeme melalui jalur formal yaitu melalui Satuan Kerja Perangkat Daerah (SKPD), lembaga pendidikan (sekolah dan pondok pesantren) dan nonformal seperti khutbah Jum'at, ceramah agama, dakwah, dan Radio Republik Indonesia. Di samping itu juga melalui organisasi sosial dan keagamaan seperti Majelis Ulama Indonesia (MUI), Forum kewaspadaan Dini Masyarakat (FKDM), Forum Kerukunan Umat Beragama (FKUB), Forum Pembauran Kebangsaan (FPK). Dengan penerapan tersebut akan dapat merajut harmoni, yaitu keselarasan, keserasian, kesesuaian, kecocokan, dan kerukunan dalam masyarakat serta bebas dari konflik horizontal. Sehingga keharmonisan pemerintah bersama masyarakat menjadi kekuatan serta aset dalam membangun negeri serta mengukir prestasi.
\end{abstract}

\begin{abstract}
:
This study is aimed to describe the implementation of anti-radicalism Islamic Education in building harmony at Sungai Penuh City. The type of the study is descriptive qualitative. the data are obtained through in-depth interview, observation, and document analysis. The result of this study revealed that the city government of Sungai Penuh has been implementing the anti-radicalism of Islamic education both formally and informally. Formally, such as government working units and Educational institutions (school, Islamic Boarding School). Informally, such as Islamic forums, speeches, and announcements through National Radio. In addition, it was promoted through non-government and religious organization. Such as MUI, FKDM, FKUB, and FPK.Through the implementation of anti-radicalism education, it was proven that they can build the harmony in society and free of horizontal conflicts. Thus, the harmony between the local government and their citizen become an asset to develop their city and governmental achievements.
\end{abstract}

Kata kunci:

Pendidikan Islam, Anti-Radikalisme, Harmoni, Sungai Penuh

INDONESIA terdiri dari 17.504 pulau, sekitar 11 ribu pulau dihuni oleh penduduk dengan 359 suku dan 726 bahasa. Ditambah lagi dengan keragaman agama yang ada sehingga Indonesia memperoleh predikat "The Meeting Place of World Religions". Hal ini menunjukkan bahwa Indonesia merupakan negara yang sangat majemuk serta 
heterogen. Sehingga dengan kemajemukan tersebut, sebagai konsekuensinya Indonesia harus menghadapi konflik-konflik yang bersumber dari perbedaan suku, agama, dan ras. Hal ini sangat berpotensi untuk menimbulkan gesekan dan konflik. Lebih parahnya lagi, akan mudah tumbuh dan berkembangnya paham radikal yang berujung merusak keharmonisan dan ketenangan dalam kehidupan bermasyarakat yang mengancam kehidupan berbangsa dan bernegara.

Radikalisme yang berujung pada terorisme menjadi masalah penting bagi umat Islam Indonesia dewasa ini. Dua isu itu telah menyebabkan Islam dicap sebagai agama teror dan umat Islam dianggap menyukai jalan kekerasan suci untuk menyebarkan agamanya. Sekalipun anggapan itu mudah dimentahkan, namun fakta bahwa pelaku teror di Indonesia adalah seorang muslim garis keras sangat membebani psikologi umat Islam secara keseluruhan. radikal merupakan blocking factor bagi eksistensi peradaban Islam di era modern (Syafaq, 2014).

Sebelum membahas pendidikan anti radikasilme lebih lanjut, ada baiknya untuk menjelaskan radikalisme terlebih dahulu. Dalam mendefinisikan pengertian radikal, beberapa ahli mengemukakan pendapat. Menurut Shadily (1984) radikal berasal dari bahasa Latin yaitu radicalis yang berarti akar suatu ikhwal. Sedangkan Qardhawi (2004) memberikan istilah radikalisme dengan istilah al-Tatarruf al-Diin. Radikalisme mempraktikkan ajaran agama dengan mengambil posisi tarf atau pinggir. Biasanya adalah sisi yang berat, memberatkan dan berlebihan. Sehingga akan menimbulkan sikap keras dan kaku. Selanjutnya pandangan yang lain, Syam (2005) dalam Mulyoto (2017) mengemukakan radikalisme secara sosiologis terjadi ketika masyarakat berada dalam situasi kesenjangan antara nilai dengan pengalamanpengalaman sehari-hari. Inti dari radikalisme adalah menghendaki adanya perubahan pergantian terhadap suatu pemerintahan di masyarakat, nilai dengan pengalaman-pengalaman sehari-hari. Inti dari radikalisme adalah menghendaki adanya perubahan pergantian terhadap suatu pemerintahan di masyarakat.

Menurut Mahmudati (2014: 30), radikalisme adalah pemikiran atau sikap yang ditandai oleh empat hal yang sekaligus menjadi karakteristiknya, yaitu: pertama, sikap tidak toleran dan tidak menghargai pendapat atau keyakinan orang lain. Kedua, sikap fanatik, yakni sikap yang membenarkan diri sendiri dan menyalahkan orang lain. Ketiga, sikap eksklusif, yakni sikap tertutup dan berusaha berbeda dengan kebiasaan orang banyak. Keempat, sikap revolusioner, yakni kecenderungan untuk menggunakan kekerasan dalam mencapai tujuan

Bila diamati secara umum di Indonesia diantara faktor pemicu terjadinya tindakan radikalisme, yaitu kesenjangan ekonomi dan sosial politik, tambah lagi dengan heterogenitas masyarakat, terjadinya diskriminatif, kemudian baru diiringi dengan faktor etnisitas maupun keragaman agama, munculnya keanekaragaman aliran, seperti paham ekstrim yang selalu menganggap kelompoknyalah yang benar sedangkan yang lain salah. Militan yakni melakukan kekerasan atas nama agama, begitu juga fundamentalis, eksklusif, dan radikal yang selalu mengklaim agamanyalah yang benar, menyalahkan yang lain, serta "saling mengkafirkan". 
Di samping itu, faktor eksternal pun cukup mempengaruhi situasi Indonesia, yaitu berbagai gerakan berakar di Timur Tengah atau tempat lain yang ingin mendirikan khilafah, entitas politik Islam universal tunggal, baik secara "damai" maupun "radikal" dan terorisme kian menampilkan diri secara terbuka. Seperti munculnya militan Negara Islam Irak dan Suriah (ISIS) yang kaki tangannya sudah menyebar ke banyak negara di dunia termasuk Indonesia, bahkan ISIS diklaim sebagai kelompok yang bertanggung jawab telah melakukan 'konser' (teror) di Indonesia. Sehingga isu global yang paling laku di bursa pasar internasional adalah terorisme yang dilakukan gerakan radikalis mengatasnamakan agama sebagai pelakunya.

Di samping itu juga diakui ada di antara masyarakat yang memiliki sikap eksklusif, ekstrim, intoleran terhadap perbedaan. Sikap eksklusif yaitu merujuk pada keyakinan atas kebenaran agama yang absolut, sehingga mengekslusi kebenaran agama lain, yang akhirnya mengandung benih ekstrim, bersikap hanya ada hitam dan putih, menganggap satu kelompok benar sedangkan lainnya salah. Seseorang dapat berbuat sesuatu yang keterlaluan, tindakan-tindakan yang berujung pada kekerasan pada kelompok yang berbeda. Selanjutnya sikap ekstrim bisa menjurus pada tindakan intoleransi yakni ketidakmampuan untuk bertoleransi yang muncul karena kita tidak bisa atau tidak mau menerima dan menghargai perbedaan. Intoleransi agama dan kultur dapat mengakibatkan tegangnya hubungan antar umat atau masyarakat pemeluk agama dan kultur yang berbeda. Dengan kondisi ini kita tidak dapat untuk membangun negeri dengan baik, karena kita sudah sibuk dalam perpecahan, bahkan jika kondisi ini berlanjut terus, maka kondisi Negara Kesatuan Republik Indonesia pun bisa terusik.

Padahal pendidikan Islam tidak mengenal radikalisme dan ekstrimisme, tapi pendidikan Islam adalah pendidikan yang damai tidak menyukai kerusakan ( fasad), radikal atau kekerasan (Q.S. Al-Baqarah [2]: 11: 205). Radikal beragama secara berlebihan sering melenceng dari ajaran syari'at yang sebenarnya, dari radikal bisa berganti menjadi ekstrim yang menjustifikasi kelompoknya yang paling benar lalu melakukan aksi tindakan kekerasan pada kelempok lain yang berbeda pendapat.

Dari fenomena-fenomena serta elobarasi di atas dapat ditarik gambaran bahwa faham radikalisme di Indonesia sudah menyebar pada setiap lini. Sikap radikalisme, saling curiga, prasangka, eksklusif dan sifat ekstrim ini hendaknya segera dihentikan atau diminimalisir agar tidak meluas, sehingga persatuan dan kesatuan bisa terjaga dengan baik. Kita harus bisa menciptakan kemajemukan Indonesia sebagai anugerah Ilahi yang patut disyukuri, sekaligus sebagai kekuatan, modal untuk kemajuan bangsa yang harus dirawat dan dikelola untuk menghadapi tantangan yang muncul di era globalisasi. Salah satu upaya yang harus dilakukan adalah dengan menerapkan pendidikan Islam anti radikalisme, yaitu pendidikan moderat, toleransi, damai, mempererat pertemanan, persaudaraan serta kasih sayang agar terciptanya keharmonisan, dengan modal inilah kita dapat membangun negeri dengan berbagai prestasi. 
Bila tindakan radikalisme tidak bisa dicegah, maka ia akan bermuara kepada terjadinya konflik. Azra (2003) mengatakan bila terjadi konflik harus diselesaikan secara demokrasi dan perdamaian, serta melalui pendidikan kewargaan, salah satu tujuan adalah civic culture yang merupakan pilar bagi pembentukan civil society (masyarakat madani). Begitu pula Abdullah (2000) menawarkan solusi yang lebih bersifat realistis yakni untuk menumbuhkan iklim tenggang rasa, simpati, dan toleran antar satu kelompok dengan lainnya dengan mengembangkan serta menciptakan keharmonisan, keselarasan, keserasian, kecocokan, kerukunan di dalam keragaman, kemajemukan masyarakat, sehingga tercipta hubungan yang rukun.

Pendidikan Islam anti radikalisme adalah usaha yang dilakukan secara sadar serta terencana melalui kegiatan pembelajaran agar anak didik atau siswa memiliki sikap menentang radikalisme (Masduqi, 2012). Secara sederhana pendidikan berbasis anti radikalisme merupakan suatu kegiatan pembelajaran yang mengarahkan peserta didiknya menjadi pribadi yang toleran, tidak radikal, dan cinta damai. Implementasi pendidikan Islam anti radikalisme dalam seluruh rangkaian kegiatan pembelajaran memiliki tiga fungsi. Pertama, membentuk akhlak peserta didik yang mulia. Kedua, sebagai usaha untuk memberantas dan menghilangkan paham radikalisme beserta ruang geraknya. Ketiga, usaha menumbuhkan generasi umat Islam yang santun, toleran, tidak radikal, serta cinta damai. Susanto (2006: 785) menyatakan bahwa pendidikan tersebut penting sebab dengan tertanamnya kesadaran demikian, sampai batas tertentu akan menghasilkan corak paradigma beragama yang hanif.

Salah satu upaya yang harus dilakukan untuk mencegah tindakan radikalisme, adalah dengan mengembangkan sikap moderat. Al-Mawardi mengungkapkan ucapan para filosof "Sifat terpuji itu adalah sifat yang berada pada posisi tengah antara dua sifat yang tercela, atau perbuatan-perbuatan baik adalah kebaikan yang berada pada posisi tengah antara dua keburukan". Sehingga dalam kerangka pendidikan kebangsaan, pendidikan agama harus diarahkan ke upaya "memoderasi" sikap keberagamaan, yaitu menjadikan orang beriman lebih bermanfaat dan menjadi umat terbaik.

Di samping moderasi juga toleransi, Badawi (1986) mengatakan, tasamuh (toleransi) adalah kesediaan untuk menerima berbagai pandangan dan pendirian yang beranekaragaman, tenggang rasa, saling menghargai dan saling menghormati. Lebih lanjut Khisbiyah (2007) menjelaskan, toleransi adalah proses membangun hubungan sosial yang lebih baik. Dengan demikian akan melahirkan kerukunan dalam berbangsa, bernegara, dan bertanah air.

Dari kebiasaan sikap moderat, toleransi, damai, suka akan ketenangan, maka pada akhirnya akan tercipta harmoni. Widjaja (2002) mengatakan bahwa harmonis sebenarnya sudah menjadi prioritas sasaran pembangunan nasional, yakni pembangunan bidang agama dan kepercayaan kepada Tuhan Yang Maha Esa yang tercermin dalam suasana kehidupan yang harmonis, serta kokohnya persatuan dan kesatuan bangsa selaras dengan penghayatan dan pengamalan pancasila. Agar manusia dapat hidup dengan penuh keserasian dan keharmonisan dengan manusia 
lain, Ia hendaknya menyeimbangkan cintanya itu dengan cinta dan kasih sayang (rahmatan lil alamin) kepada orang lain, dapat bekerja sama atau memberi bantuan kepada mereka, suka berbagi kepada sesama, memiliki kepedulian, mencintai orang lain seperti ia mencintai dirinya sendiri, terutama terhadap orang yang memerlukan bantuan.

Dalam penerapan pendidikan anti radikalisme ada beberapa hal yang harus diperhatikan di antaranya:

1. Tokoh masyarakat sebagai penggerak kegiatan keagamaan harus selektif dalam memberikan pemahaman keagamaan.

2. Masyarakat harus mengajarkan nilai-nilai multikultural yang menghargai segala bentuk perbedaan yang ada dalam masyarakat.

3. Menghindari segala konflik suku, agama, dan ras dalam masyarakat. Namun yang harus dihidupkan adalah kerukunan antar suku, agama dan ras yang ada dalam masyarakat tersebut, sehingga dengan ini akan tercipta kehidupan masyarakat yang aman, damai, dan terhindar dari pengaruh radikalisme dan terorisme (Alhairi, 2017).

Di samping itu, dalam menciptakan kondisi yang tertib dan harmonis, Kahmad (2000) memaparkan beberapa hal yang perlu dilakukan diantaranya:

1. Perlu adanya penambahan orientasi pendidikan agama yang tidak hanya menekankan aspek sektoral fiqhiyah tetapi juga menekankan aspek universalrabbaniyah

2. Melakukan kegiatan sosial yang melibatkan para pemeluk agama yang berbeda dan menghindari sikap egoisme dalam beragama sehingga mengklaim diri paling benar

3. Perlu ditonjolkan segi-segi persamaan dan tidak memperdebatkan segi-segi perbedaan.

Suasana harmonis ini memang seharusnya dapat diciptakan dalam kehidupan yang penuh keragaman baik agama maupun suku, karena manusia memang diciptakan dalam keragaman. Allah telah menjadikan manusia dengan beberapa umat (Q.S. Al- An'am [6]: 42), atau beberapa kaum (Q.S. Al-An-fal [8]: 53). Begitu juga Allah menakdirkan adanya berbagai suku dan bangsa (Q.S. Al-Hujurat [49]: 13). Ayat ini menerangkan bahwa kita di ciptakan Allah bukan dalam keseragaman, tetapi dalam keragaman dan perbedaan. Keragaman adalah sunnatullah yang tidak bisa diingkari. Seperti yang ditulis Setiawan (2012), keragaman bukanlah sesuatu yang negatif, melainkan suatu situasi yang memberikan kontribusi positifnya secara optimal.

Perbedaan manusia dalam bahasa dan warna kulit harus diterima sebagai sebuah kenyataan positif (Q.S. Ar-Rum [30]: 22). Perbedaan tidak perlu digusarkan dalam hidup, dan hendaklah dipergunakan sebagai kekuatan dan pangkal tolak berbuat kebajikan. Adapun yang terpenting dalam keragaman tersebut adalah terciptanya kedamaian di antara mereka. Islam adalah agama yang sangat mencintai perdamaian dan orang yang condong pada perdamaian tersebut."Dan jika mereka 
condong kepada perdamaian, maka condonglah kepadanya dan bertawakkallah kepada Allah" (Q.S. Al Anfaal [8]: 62). Menurut Ahmadi (1995: 274), Nabi Muhammad SAW tidak pernah menolak untuk hidup damai, selalu menerima ajakan perdamaian, kendatipun selalu dihianati oleh kaum musuh. Beliau bahkan mengajarkan kepedulian, belas kasih dan upaya menghapus kesedihan dan penderitaan bagi sesama. Kasih sayang orang mukmin itu tidak terbatas pada saudara-saudaranya yang mukmin saja, tetapi bahkan melimpah untuk seluruh umat manusia.

Seiring dengan meningkatnya gerakan radikalisme di Indonesia, maka pendidikan Islam anti radikalisme menjadi suatu kebutuhan dalam menghadapi gelombang perubahan dan tantangan kelompok radikal. Sebagaimana yang terdapat di Kota Sungai Penuh Provinsi Jambi, dengan karakteristik masyarakat yang heterogen dan kemajemukan suku, tradisi budaya, bahasa, dan agama. Namun kondisi masyarakatnya terlihat jauh dari sifat radikalisme, mereka dapat merajut harmoni dan penuh kedamaian serta toleransi saling menghargai dan menghormati keberagaman. Dengan semangat bergotong royong, kerja sama yang baik, saling menghargai, bersatu dalam keragaman tanpa melihat perbedaan agama, suku, budaya dan bahasa, mereka dapat membangun negeri, meraih prestasi dalam era globalisasi. Ini merupakan kearifan lokal yang khas patut untuk ditiru, dicontoh serta dipedomani. Untuk memahami secara lebih konkrit dan mendalam, maka perlu dilakukan melalui penelitian. Penelitian ini diharapkan dapat mengemukakan suatu gambaran "Bagaimana Penerapan Pendidikan Islam Anti Radikalisme dalam Merajut Harmoni untuk Membangun Negeri di Kota Sungai Penuh Jambi".

Berangkat dari latar belakang di atas, tulisan ini sengaja diangkat karena melihat fenomena-fenomena yang berkembang dewasa ini, di mana radikalisme (baca: kekerasan) yang terjadi di belahan muka bumi, termasuk di Indonesia. Sehingga perlu dilihat bagaimana Pemerintah Kota Sungai Penuh menerapkan pendidikan Islam anti radikalisme dalam merajut harmoni untuk menciptakan masyarakat yang damai dan rukun di tengah heterogenitas masyarakatnya.

\section{METODE PENELITIAN}

Metode yang digunakan dalam penelitian ini adalah metode deskriptif dengan pendekatan kualitatif. Penggunaan metode dan pendekatan tersebut mengingat bahwa tujuan dari penelitian ini adalah untuk mendeskripsikan dan menganalisis tentang bagaimana penerapan pendidikan Islam anti radikalisme dalam merajut harmoni di Kota Sungai Penuh. Pengumpulan data kualitatif dilakukan dengan metode wawancara, observasi dan telaah dokumen. Penelusuran data primer dilakukan melalui wawancara dengan nara sumber kunci (key informan) untuk mengetahui berbagai peran yang dimiliki, yaitu Satuan Kerja Perangkat Daerah (SKPD), Ketua Majelis Ulama Indonesia (MUI), Ketua Forum Kerukunan Umat Beragama (FKUB), Ketua Forum Pembauran Kebangsaan, Pengawas dan Guru Agama di Kota Sungai Penuh. Wawancara dilakukan untuk mengetahui cara pemerintah menerapkan pendidikan Islam anti radikalisme. Observasi dilakukan 
untuk mengangkat realita secara lebih utuh, menangkap dan memahami fenomena serta kondisi riil yang sebenarnya, mengamati objek penelitian, terhadap proses komunikasi pemerintah dan jajaran dengan masyarakat dalam hal, sosialisasi dan implementasi pendidikan anti radikalisme, kondisi perilaku masyarakat, serta hasilhasil pembangunan yang telah dicapai oleh pemerintah Kota Sungai Penuh. Telaah dokumen dilakukan terhadap literatur yang relevan dengan pendidikan anti radikalisme dan Warta Kota Majalah Kota Sungai Penuh. Analisa data kualitatif dilakukan sebelum, selama dan setelah pengumpulan data. Diawali dari pengumpulan teori, begitu juga selama penelitian berlangsung. Data dan informasi yang terkumpul dikoding dan direduksi kemudian secara berlanjut akan diinterpretasi dan dianalisis lebih dalam, akhirnya disajikan secara deskriptif dalam bentuk tulisan naratif.

\section{HASIL PENELITIAN DAN PEMBAHASAN}

Pemerintah kota Sungai Penuh dalam menerapkan pendidikan anti radikalisme, terlebih dahulu mensosialisasikan pendidikan Islam anti radikalisme tersebut kepada seluruh jajaran pemerintah dan masyarakat dengan menggunakan jalur yang bersifat formal dan non formal. Adapun jalur formal dilakukan oleh pemerintah sendiri melalui apel bendera setiap Satuan Kerja Perangkat Daerah (SKPD) yang dilaksanakan pada pagi senin. Di samping amanat, peserta upacara disuguhkan dengan santapan rohani atau pendidikan agama tujuh menit (kultum). Di antara materinya berisikan pendidikan Islam anti radikalisme, agar tidak melakukan tindakan anarkis, menciptakan dan menjaga keamanan dan ketertiban di lingkungan masing-masing, dan menjaga keharmonisan dalam bekerja. Di samping itu sosialisasi juga dilakukan melalui lembaga pendidikan formal baik sekolah maupun madrasah dari tingkat PAUD sampai SLTA. Pada apel bendera senin pembina upacara memberikan amanat yang berhubungan dengan pendidikan anti radikalisme dan damai. Pada tiap hari Jum'at dilakukan kegiatan mengaji bersama, pembacaan Surat Yasin (yasinan), tahlil dan doa bersama, agar negeri dan bangsa ini tetap aman, tertib dan damai. Hal ini sesuai dengan temuan Thoyyib (2018), bahwa cara tepat dalam mengantisipasi radikalisme di Indonesia adalah melalui jalur Peran Pemerintah dalam mensosialisasikan pendidikan Islam anti radikalisme dengan melibatkan instansi Pemerintah, peran institusi keagamaan dan pendidikan peran masyarakat sipil. Seperti sosialisasi yang dilakukan melalui jalur non formal yang dilakukan melalui khutbah jumat, ceramah antara maghrib dan isya, setelah subuh, Badan Kontak Majelis Ta'lim yang memiliki jaringan dari tingkat kota sampai ke RT/RW, Remaja Masjid, pengajian TPA/ TPSA dan sarana lainnya di Kota Sungai Penuh.

Atas nama pemerintah, Wali Kota Sungai Penuh selalu mengajak dan menghimbau pada seluruh masyarakat kota Sungai Penuh untuk menghindari perbuatan radikal, tawuran, membuat kerusakan, serta dapat mengimplementasikan nilai toleransi dalam kehidupan sehari-hari. Ajakan dan himbauan ini disampaikan 
pada siaran RRI Kota Sungai Penuh secara berkala. Beliau juga menyampaikan pada tiap peringatan hari besar Islam, safari Ramadhan, hari raya Idul Fitri, Idul Adha dan kesempatan lainnya. Dengan demikian akan tercipta keamanan dan ketertiban. Khisbiyah (2007) menjelaskan, toleransi adalah proses membangun hubungan sosial yang lebih baik. Dengan demikian akan melahirkan kerukunan dalam berbangsa, bernegara, dan bertanah air.

Dalam kehidupan bermasyarakat, jika terjadi kasus-kasus yang diduga bisa menimbulkan tindakan radikalisme maupun konflik antar desa, maka diselesaikan secara adat dan diupayakan agar tidak membesar. Pemerintah Kota Sungai Penuh menyelesaikan secara tuntas, dengan melakukan rekonsiliasi, perdamaian, kerukunan kembali. Dengan mencari titik temu (kalimatunsawa) dan penyelesaian menggunakan prinsip "kemenangan bersama" (win-win solution). Sehingga dengan demikian masyarakat merasa puas dan tidak lagi mengulangi perbuatan-perbuatan yang merugikan orang lain dan diri sendiri. Masyarakat merasa tidak didiskriminasi dan diperlakukan secara tidak adil. Pihak-pihak yang bertikai menerima keputusan atau perdamaian dengan lapang dada dan tidak berniat lagi untuk mengulangi perbuatan tersebut. Kriesberg (1998) menuliskan bahwa untuk menyelesaikan konflik damai dan menjadi sesuatu yang konstruktif bisa melalui mekanisme internal kelompok, antar kelompok dan luarnya (ekstra). Jika diletakkan dalam konteks konflik agama, maka konflik itu bisa diselesaikan melalui mekanisme intra-agama, inter-agama, dan ekstra-agama. Lebih lanjut, Azra (2003) berpendapat bahwa bila terjadi konflik harus diselesaikan secara demokrasi dan perdamaian, serta melalui pendidikan kewargaan. Abdullah (2000) menawarkan solusi dengan menumbuhkan iklim tenggang rasa, simpati, dan toleran antar satu kelompok dengan lainnya dengan mengembangkan serta menciptakan keharmonisan, keselarasan, keserasian, kecocokan, kerukunan di dalam keragaman, kemajemukan masyarakat, sehingga tercipta hubungan yang rukun.

Berdasarkan hasil wawancara dalam mengantisipasi tindakan radikal, Majelis Ulama Indonesia Kota Sungai Penuh menerapkan sikap moderat dengan melaksanakan pendidikan dan latihan terhadap para ulama, khatib, muballiq, da'i, guru mengaji agar dapat memahami pendidikan Islam anti radikalisme yang sebenarnya, untuk disosialisasikan, diinternalisasi dan diimplementasikan oleh masyarakat secara luas. Adapun penerapan pendidikan anti radikalisme dalam lingkungan masyarakat di antaranya tokoh masyarakat sebagai penggerak kegiatan keagamaan harus selektif dalam memberikan pemahaman keagamaan. Jangan sampai memberikan pemahaman agama yang radikal yang pada akhirnya mereka terjangkit penyakit radikalisme (Alhairi, 2017). Kriesberg (1998) menyatakan bahwa masyarakat dapat mengembangkan kepemimpinan yang pro-perdamaian atau kepemimpinan positif. Tersedianya tokoh dan pemimpin agama semacam ini dapat menjadi penyeimbang dan alternatif kepada munculnya kepemimpinan negatif, yaitu mereka yang mendukung kekerasan dan memobilisasi umat dalam rangka kekerasan kolektif. Selaras dengan ini, para pemimpin agama juga dapat dididik di bidang 
toleransi, sikap saling menghargai, dan hidup berdampingan secara damai. Hal ini didukung oleh Susanto (2006: 785) yang menyatakan bahwa pendidikan seperti yang diuraikan di atas penting sebab dengan tertanamnya kesadaran demikian, sampai batas tertentu akan menghasilkan corak paradigma beragama yang hanif.

Dalam bidang pendidikan, Upaya penerapan anti radikalisme secara dini dilakukan melalui lembaga pendidikan. Sebagaimana hasil wawancara dengan pengawas pada Kementerian Agama Kota Sungai Penuh, beliau mengatakan melalui jalur pendidikan berdasarkan Peraturan Menteri Pendidikan dan Kebudayaan nomor 69 tahun 2013 Tentang Kerangka Dasar dan Struktur Kurikulum Sekolah Menengah Atas/Madrasah Aliyah, pada kompetensi dasar pendidikan agama dan budi pekerti, terdapat salah satu pokok bahasan menghayati dan mengamalkan sifat peduli (gotong-royong, kerja sama, toleran, damai). Maka pengawas sudah menekankan agar guru agama di madrasah dan sekolah dapat menginternalisasi nilai ini secara maksimal, dan siswa dapat mengimplementasi dalam lingkungan sekolah, keluarga dan masyarakat secara luas. Lingkungan sekolah merupakan salah satu tempat yang efektif untuk mengajarkan dan menerapkan nilai-nilai anti radikalisme. Oleh karena itu, dalam kerangka pendidikan kebangsaan, pendidikan agama harus diarahkan ke upaya "memoderasi" sikap keberagamaan, yaitu menjadikan orang beriman lebih bermanfaat dan menjadi umat terbaik. Hal ini didukung oleh hasil penelitian Wiyani (2013) yang melihat implementasi Pendidikan Agama Islam Berbasis Anti Terorisme Di SMA, Mantu (2015) hubungan dalam membina kedamaian yang terjalin antara warga pesantren dan masyarakat merupakan salah satu strategi gerakan counterradikalisme, serta Noorhayati (2017) yang menyatakan bahwa Pesantren dapat menjadi solusi alternatif dalam membendung radikalisme dan terorisme kontemporer.

Di samping itu upaya penerapan anti radikalisme di tiap madrasah dan sekolah pada pagi Jum'at sebelum melakukan proses pembelajaran dilakukan ngaji bersama, mulai dengan yasinan, kultum dan do'a. Dengan demikian toleransi mereka akan semakin tinggi, sesama siswa akan merasa bersahabat, pertemanan antara mereka akan semakin erat. Hal ini sesuai dengan prinsip Pendidikan Islam anti radikalisme yang merupakan usaha yang dilakukan secara sadar serta terencana melalui kegiatan pembelajaran agar anak didik atau siswa memiliki sikap menentang radikalisme (Masduqi, 2012). Namun hal ini belum cukup. Maka perlu adanya penambahan orientasi pendidikan agama yang tidak hanya menekankan aspek sektoral fiqhiyah tapi juga menekankan aspek universal-rabbaniyah (Kahmad, 2000).

Lebih lanjut, Dalam mencegah tindakan radikalisme Pemerintah Kota Sungai Penuh melakukan secara moderat, selalu bertindak melalui jalan tengah yang adil, sehingga masyarakat merasa tidak dirugikan dan kondisi masyarakat akan selalu kondusif serta dapat melaksanakan kegiatan rutin sebagaimana biasanya. Sesuai dengan hasil pengamatan yang dilakukan, terlihat suasana masyarakat selalu damai, harmonis, aman dan tertib, mereka saling senyum, berjabat tangan saat bertemu dan menjalin persaudaraan serta melakukan aktifitas sesuai dengan profesi masing- 
masing. Dengan menerapkan sikap moderat ini akan dapat diterima oleh semua pihak secara lapang dada dan sama-sama senang, tidak ada yang merasakan dirugikan. Upaya mencegah radikalisme pemerintah membentuk Forum Kewaspadaan Dini Masyarakat (FKDM) yang merupakan elemen strategis baik untuk hubungan horizontal maupun hubungan vertikal, yakni untuk menciptakan situasi kondusif, terkhusus dengan gangguan keamanan serta untuk mengajak masyarakat lebih persuasif tatkala menemukan adanya potensi terjadinya kekerasan dan konflik serta tidak menimbulkan ketidaknyamanan di tengah masyarakat. Hal ini sesuai dengan upaya penganggulangan radikalisme yang diusulkan oleh Ruslan (2015) yakni dengan menanamkan kesadaran yang setinggi-tingginya (mengarahkan) kepada masyarakat sebagai makhluk yang berbudaya yang memiliki kemampuan untuk mengolah akal dan pikiran bahwasanya tindakan radikal adalah sangat tidak layak untuk dilakukan oleh masyarakat yang memiliki akal dan pikiran. Kapasitas yang paling tepat untuk memberikan pengarahan pada usaha ini adalah para tokoh agama dengan cara memberikan pemahaman bahwa agama sangat melarang tindakan radikal, karena itu termasuk perbuatan yang dilarang oleh agama.

Berdasarkan hasil wawancara dengan Ketua Forum Kerukunan Umat Beragama (FKUB) Kota Sungai Penuh, di Kota Sungai Penuh terdapat bermacam agama, yaitu: Islam, Kristen Protestan, Kristen Khatolik, Hindu, Budha dan Konghucu. Dalam forum ini semua agama terwakili sebagai pengurus. Berdasarkan kesepakatan semua agama telah bertekad untuk menciptakan serta mewujudkan harmoni dan kedamaian antar umat beragama, salah satunya melalui forum ini yang mengedepankan sikap moderat, toleransi, saling percaya, tidak saling mengganggu dan selalu mengedepankan kebersamaan. Dengan kerja keras FKUB maka Kota Sungai Penuh mendapat penghargaan Harmony Award dari Kementerian Agama RI tahun 2017. Hal ini menunjukkan bahwa fungsi edukatif dan memupuk persaudaraaan dari agama sebagaimana yang dituliskan oleh Hendropuspito (1998) telah berjalan di Kota Sungai penuh dengan Melakukan kegiatan sosial yang melibatkan para pemeluk agama yang berbeda dan menghindari sikap egoisme dalam beragama sehingga mengklaim diri paling benar (Kahmad, 2000).

Begitu juga terhadap keragaman suku atau etnis Kota Sungai Penuh telah membentuk Forum Pembauran Kebangsaan (FPK). Berdasarkan hasil wawancara dengan Ketua FPK, diperoleh informasi bahwa di Kota Sungai Penuh terdapat beberapa suku, yaitu Suku Kerinci, Jambi, Minang, Batak Muslim, Batak Kristen, Jawa, Palembang, Melayu, dan Cina. Sedangkan berdasarkan pengamatan masih banyak suku lain yang belum terhimpun ke dalam forum ini seperti suku Aceh, Riau, Bengkulu, Banjar dan lainnya. Forum ini telah menyepakati untuk tetap bersatu dengan menjalin komunikasi secara berkala serta tetap menjaga persatuan dan kesatuan dengan menghargai perbedaan, untuk selalu mengedepankan kebersamaan, agar tercipta keharmonisan dan kedamaian di tengah masyarakat. Mereka hidup dengan semangat membangun keharmonisan dan perdamaian,untuk mencapai kesejahteraan bersama, dengan selalu mengedepankan empat pilar kebangsaan, yaitu 
“Undang-undang Dasar 1945, Pancasila, Bhinnika Tunggal Ika, dan Negara Kesatuan Republik Indonesia". Mengenal Indonesia dalam aspek agama dengan kaca pandang sejarah diharapkan memunculkan sikap toleran diimbangi dengan nasionalisme setiap generasi untuk mewujudkan kerukunan Intern dan lintas agama. Di samping hal tersebut juga perlu ditonjolkan segi-segi persamaan dan tidak memperdebatkan segi-segi perbedaan (Kahmad, 2000).

Berdasarkan hasil wawancara dengan tokoh masyarakat diperoleh informasi bahwa masyarakat Kota Sungai Penuh sejak dulu sudah sangat hetrogen, multi kultur yang berasal dari berbagai daerah di Indonesia, namun kedatangan mereka mendapat sambutan serta respon yang positif dari penduduk asli. Mereka sangat menghargai serta menghormati keberadaan para perantau dari luar daerah dengan bermacam suku, etnis. Bahkan mereka hidup bertetangga, dapat berteman, bersahabat, saling cinta dan kasih sayang yang dipatri dengan perkawinan antar suku, berketurunan, beranak dan bercucu. Mereka sudah merasakan bahwa hidup ini harus harmoni dapat berbagi keberagaman, dan ini merupakan keharusan yang harus dipelihara, dirawat, dirajut agar terbentuk suatu kekuatan dalam meraih citacita. Masyarakat harus mengajarkan nilai-nilai multikultural yang menghargai segala bentuk perbedaan yang ada dalam masyarakat.Ketiga, menghindari segala konflik suku, agama, dan ras dalam masyarakat. Namun yang harus dihidupkan adalah kerukunan antar suku, agama dan ras yang ada dalam masyarakat tersebut, sehingga dengan ini akan tercipta kehidupan masyarakat yang aman, damai, dan terhindar dari pengaruh radikalisme dan terorisme (Alhairi, 2017).

Apabila harmoni sudah terajut, kasih sayang sudah terjalin, kedamaian akan tercipta, keadilan akan terwujud dengan baik, negeri akan bebas dari konflik, perselisihan, pertentangan dan gangguan, serta suka akan ketenangan dan keamanan. Dengan demikian pemerintah bersama masyarakat akan mudah untuk melakukan pembangunan di segala bidang. Sebagaimana yang terdapat di Kota Sungai Penuh dengan terajutnya harmoni dalam keberagaman, maka pemerintah akan mudah dalam melaksanakan pembangunan, sehingga beberapa prestasi dapat diraih pada tingkat Provinsi Jambi. Begitu juga tingkat nasional, diantaranya penganugerahan Tanda Kehormatan Satya Lancana pembangunan dari Presiden RI, penghargaan Wahana Tata Nugraha (WTN) dari Kementerian Perhubungan RI. Meraih opini Wajar Tanpa pengecualian (WTP) dalam hal pengelolaan keuangan daerah dari BPK RI. Meraih sertifikat dan piala Adipura Lambang Supremasi tertinggi untuk Kota Bersih, Teduh dan Berkelanjutan 2015. Penghargaan Sekolah peduli dan berbudaya lingkungan dari Kementerian Pendidikan dan Kebudayaan RI. Dan Kementerian Lingkungan Hidup dan Kehutanan. Dengan demikian Kota Sungai penuh yang merupakan bagian dari bangsa Indonesia telah berpartisipasi dalam membangun bangsa, memperkuat negara Kesatuan Republik Inonesia (NKRI) yang berdasarkan Pancasila dan UUD 1945.

Oleh karena itu, untuk mencegah radikalisme harus melalui proses kemanusiaan, sebagai upaya memahami orang lain sebagai teman (sahabat) menjadi 
keniscayaan. Sebab, saat mereka terus mendapat tekanan dan serangan atas nama kontra terorisme misalnya, maka yang terjadi adalah munculnya benih kebencian baru. Saat benih itu muncul, maka kelompok yang sebelumnya tidak bersimpati terhadap teroris mendapat kesempatan (legitimasi) untuk melakukan hal yang serupa atas nama kebenaran dan kebaikan, bahkan makin radikal. Maka deradikalissasi selayaknya terbangun dari cara-cara humanis, dari fondasi kemanusiaan, melalui pendekatan budaya, pemanusiaan yang pada gilirannya mereka akan sadar sendiri, serta akan mengakhiri laku kekerasan bahkan mau bertobat, bukan dengan melakukan kekerasan, apalagi dengan memanggul senjata.

\section{SIMPULAN}

Secara umum pemerintah Kota Sungai Penuh telah berhasil merajut harmoni dalam keberagaman, dengan menciptakan kedamaian, kasih sayang, kepedulian, keadaban, ketenangan, dan keamanan. Dengan demikian Kota Sungai Penuh dapat melaksanakan pembangunan secara merata dan berkeadilan. Dibuktikan lagi dengan banyak mendapat penghargaan, penganugerahan, sertifikat, atas keberhasilan dalam membangun, serta prestasi-prestasi yang berhasil diraih di tingkat provinsi dan nasional.

Implementasi pendidikan anti radikalisme di Kota Sungai Penuh dan daerahdaerah lain perlu terus dikembangkan, dibudayakan, dibiasakan, dikondisikan secara terus menerus dalam kehidupan keseharian di tengah masyarakat. Berdasarkan hasil penelitian direkomendasikan kepada pemerintah Kota Sungai Penuh untuk terus menerus bekerja sama dengan para ulama dalam menginternalisasi, mensosialisasi, dan mengimplementasi pendidikan anti kekerasan, agar suasana menjadi aman dan tertib, pembangunan dapat terlaksana dengan merata, masyarakat bisa merasa sejahtera dan bahagia.

\section{DAFTAR PUSTAKA}

Abdullah, M. A. (2000). Dinamika Islam Kultural Pemetaan atas Wacana Keislaman Kontemporer. Bandung: Mizan.

Ahmadi, K. A. (1995). Perang dan Damai dalam Islam. Bandung: Pustaka Setia.

Alhairi. (2017). Pendidikan Anti Radikalisme: Ikhtiar Memangkas Gerakan Radikal. Jurnal Tarbawi, 14(2), 109-122. Retrieved from https://ejournal.unisnu.ac.id/JPIT/article/download/617/911

Azra, A. (2003). Pengantar dalam Dede Rosyada, Pendidikan Kewargaan (Civic Education): Demokrasi, Hak Asasi Manusia \& Masyarakat Madani. Jakarta: ICCE UIN Syarif Hidayatullah.

Badawi, Z. (1986). Mu'jam Musthalahat Al-Ulum Al-Ijtima'yat. Beirut: Maktubah Lubnan.

Hendropuspito, O. C. D. (1998). Sosiologi Agama. Yogyakarta: Kanisius. 
Kahmad, D. (2000). Sosiologi Agama. Bandung: Rosda.

Khisbiyah, Y. (2007). Menepis Prasangka, Memupuk Toleransi untuk Multikultural: Dukungan dan Psikologi Sosial. Surabaya: PSB-PS UMS.

Kriesberg, L. (1998). International Conflict Resolution: from Escalation to Resolution. Maryland: Rowman \& Littlefield.

Mahmudati, Z. (2014). "PeTe" Pendidikan Anti Terorisme Sejak Dini Solusi Menanamkan Wawasan Kebangsaan bagi Generasi Bangsa. Jurnal Ilmiah Mahasiswa, 4(1), 65-78. Retrieved from https://ejournal.undip.ac.id/index.php/jim/article/view/10887

Mantu, R. (2015). Bina-Damai dalam Komunitas Pesantren: Sebuah Upaya CounterRadikalisme. Walisongo, 23(1), 131-150. Retrieved from http://journal.walisongo.ac.id/index.php/walisongo/article/view/227/208

Masduqi, I. (2012). Deradikalisasi Pendidikan Islam Berbasis Khazanah Pesantren. Jurnal Pendidikan Islam, 2(1), 3-14. Retrieved from http://ejournal.uinsuka.ac.id/tarbiyah/JPI/article/view/1125

Mulyoto, G. P. (2017). Radikalisme Agama di Indonesia (Ditinjau dari Sudut Pandang Sosiologi Kewarganegaraan). Citizenship Jurnal Pendidikan Pancasila Dan Kewarganegaraan, 5(1), 64-74. Retrieved from http://ejournal.unipma.ac.id/index.php/citizenship/article/download/1212/1053

Noorhayati, S. M. (2017). Pendidikan Multikultural di Pesantren (Upaya Membendung Radikalisme di Indonesia). Madania, 21(1), 67-78. Retrieved from

http:// ejournal.iainbengkulu.ac.id/index.php/madania/article/download/2 12/pdf_1

Qardhawi, Y. (2004). Islam Radikal: Analisis terhadap Radikalisme dalam Berislam dan Upaya Pemecahannya. Solo: Intermedia.

Ruslan, I. (2015). Islam dan Radikalisme: Upaya Antisipasi dan Penanggulangannya. Kalam: Jurnal Studi Agama Dan Pemikiran Islam, 9(2), 215-232. Retrieved from http:/ / ejournal.radenintan.ac.id/index.php/KALAM/article/view/329/185

Setiawan, M. N. (2012). Pribumisasi Al-Qur'an: Tafsir Berwawasan Keindonesiaan. Yogyakarta: Kankaba.

Shadily, H. (1984). Sosiologi untuk Masyarakat Indonesia. Jakarta: Rineka Cipta.

Susanto, E. (2006). Pendidikan Agama Berbasis Multikultural (Upaya Strategis Menghindari Radikalisme). Karsa, 9(1), 77-85. Retrieved from https://www.researchgate.net/profile/Edi_Susanto7/publication/268409821 _PENDIDIKAN_AGAMA_BERBASIS_MULTIKULTURAL_Upaya_Strategis_ Menghindari_Radikalisme/links/5593e83308ae5af2b0ecd053.pdf

Syafaq, H. (2014). Radikalisme sebagai Blocking Factor bagi Perkembangan Peradaban Islam Modern. Teosofi: Jurnal Tasawuf Dan Pemikiran Islam, 4(2), 451476.

Retrieved

from http://teosofi.uinsby.ac.id/index.php/teosofi/article/view/18

Thoyyib, M. (2018). Radikalisme Islam Indonesia. Ta'lim : Jurnal Studi Pendidikan Islam, 1(1), 90-105. Retrieved from https://media.neliti.com/media/publications/264716-radikalisme-islamindonesia-655c46eb.pdf

Widjaja, H. A. W. (2002). Pedoman Pelaksanaan Pendidikan Pancasila pada Perguruan 
Tinggi. Jakarta: Raja Grafindo Persada.

Wiyani, N. A. (2013). Pendidikan Agama Islam Berbasis Anti Terorisme di SMA. Jurnal Pendidikan Islam, 2(1), 65-83. Retrieved from http://ejournal.uinsuka.ac.id/tarbiyah/JPI/article/view/1128 